\title{
Rhabdomyolysis in a Healthy Peripheral Blood Stem Cell Donor following Mobilization with Filgrastim
}

\author{
Sibel Hacioglu ${ }^{a} \quad$ Fevzi Altuntas ${ }^{b} \quad$ Leylagul Kaynar $^{\mathrm{b}} \quad$ Ismail Sari ${ }^{\mathrm{a}} \quad$ Turkan Patiroglu $^{\mathrm{c}}$ \\ Mustafa Cetin ${ }^{b}$ \\ a Department of Hematology, Pamukkale Medical School, Denizli, \\ ${ }^{b}$ Department of Hematology and Apheresis Unit, Erciyes Medical, \\ ${ }^{c}$ Department of Pediatric Hematology, Erciyes Medical School, Kayseri, Turkey
}

\section{Key Words}

Rhabdomyolysis · Filgrastim .

Peripheral blood stem cell mobilization

\section{Summary}

Background: Although granulocyte colony stimulating factor (G-CSF) mobilization is generally well tolerated by healthy donors, there is also a wide spectrum of adverse events associated with it. Among these events, rhabdomyolysis in peripheral blood stem cell (PBSC) donors is very rare. In this paper, we present a first case of rhabdomyolysis after administration of filgrastim for PBSC mobilization. Case Report: A 6-year-old donor received $10 \mu \mathrm{g} / \mathrm{kg} /$ day filgrastim subcutaneously for 5 days. On the 3rd day of filgrastim, the donor complained of bone pain; a single dose of paracetamol $(250 \mathrm{mg})$ was given to relieve pain. On the 4th day, she complained of bone pain, myalgia, and vomiting. On laboratory analysis, serum creatine phosphokinase was 1,095 U/l (40-226 U/I), LDH $312 \mathrm{U} / \mathrm{I}(100-190 \mathrm{U} / \mathrm{l})$, aspartate aminotransferase $85 \mathrm{U} / \mathrm{I}$ (0-40 U/l), potassium $3.3 \mathrm{mmol} / \mathrm{l}(3.6-5.1 \mathrm{mmol} / \mathrm{l})$. Urine myoglobin was $110 \mathrm{ng} / \mathrm{ml}(<5 \mathrm{ng} / \mathrm{ml})$. Rhabdomyolysis was suspected on clinical and laboratory findings. Clinical manifestations regressed and the laboratory results returned to normal within three days after intravenously forced diuresis and potassium replacement. Stem cells were successfully harvested from peripheral blood on the 5th day of G-CSF therapy. Conclusion: Rhabdomyolysis is a rare but important adverse effect of G-CSF. Allogeneic PBSC donors should be closely monitored with regard to rhabdomyolysis after G-CSF administration in the mobilization setting.

\section{Schlüsselwörter}

Rhabdomyolyse · Filgrastim .

Mobilisation peripherer Blutstammzellen

\section{Zusammenfassung}

Hintergrund: Die Mobilisation von Blutstammzellen mit Granulozyten-Kolonie stimulierendem Faktor (G-CSF) ist für gesunde Spender im Allgemeinen gut verträglich. Das Spektrum möglicher unerwünschter Nebenwirkungen von G-CSF ist vielfältig. Eine Rhabdomyolyse tritt bei Spendern von peripheren Blutstammzellen (PBSC) äußerst selten auf. In der vorliegenden Arbeit stellen wir einen ersten Fall von Rhabdomyolyse nach der Gabe von Filgrastim zur Mobilisation der PBSC vor. Fallbericht: Eine 6-jährige Spenderin erhielt 5 Tage lang subkutan $10 \mu \mathrm{g} / \mathrm{kg} / \mathrm{Tag}$ Filgrastim. Am 3. Tag der Filgrastim-Gabe klagte die Spenderin über Knochenschmerzen, die mit einer einzelnen Dosis Paracetamol (250 mg) behandelt wurden. Am 4. Tag klagte sie über Knochenschmerzen, Myalgie und Erbrechen. Bei der Laboranalyse waren die Serumwerte für Creatinin-Phosphokinase $1095 \mathrm{U} / \mathrm{I}$ (40-226 U/I), für LDH 312 U/I (100-190 U/I), für Aspartat-Aminotransferase $85 \mathrm{U} / \mathrm{l}(0-40 \mathrm{U} / \mathrm{l})$ und für Kalium 3,3 mmol/l (3,6-5,1 mmol/l). Der Myoglobinwert im Harn betrug $110 \mathrm{ng} / \mathrm{ml}(<5 \mathrm{ng} / \mathrm{ml}$ ). Aufgrund der klinischen und labortechnischen Untersuchungen wurde eine Rhabdomyolyse vermutet. Drei Tage nach einer intravenös forcierten Diurese und einer Kaliumsubstitution bildeten sich die klinischen Erscheinungsformen zurück und die Laborwerte normalisierten sich. Die Stammzellen konnten am 5. Tag der G-CSF-Therapie aus dem peripheren Blut entnommen werden. Schlussfolgerung: Die Rhabdomyolyse ist eine seltene, aber bedeutende unerwünschte Nebenwirkung der G-CSF-Mobilisation. Während der Mobilisierung mit G-CSF sollten allogene PBSC-Spender sorgfältig im Hinblick auf eine Rhabdomyolyse überwacht werden.

\begin{tabular}{ll}
\hline KARGER & $\oplus$ 2009 S. Karger GmbH, Freiburg \\
Fax +497614520714 & Accessible online at: \\
Information@Karger.de & www.karger.com/tmh \\
www.karger.com &
\end{tabular}




\section{Introduction}

Granulocyte colony stimulating factor (G-CSF) has been considered as the standard mobilizing agent for peripheral blood stem cell (PBSC) donors. Mobilization with G-CSF is generally well tolerated by the healthy donor; however, there is also a wide spectrum of adverse events associated with it. Common manageable toxicities are bone pain, fever, and reversible elevations of alkaline phosphatase (ALP), lactate dehydrogenase (LDH), aspartate aminotransferase (AST), and uric acid. Rare but serious and life-threatening toxicities such as thrombosis, myocardial infarction, adult respiratory distress syndrome, and splenic rupture may also occur [1]. Among healthy individuals, three patients are known to have developed acute myeloid leukemia 1-5 years subsequent to G-CSF administration [2]. Consequently, in recent years, questions have been raised concerning the safety of G-CSF in this setting.

Rhabdomyolysis is a syndrome that involves damage and breakdown of skeletal muscle, resulting in the release of muscle cell contents into the systemic circulation, in association with a number of clinical triggers across the age spectrum. It presents with a classic triad of muscle pain, weakness, and brown urine [3]. However, in a recent series, only 1 of 191 pediatric patients presented with all findings [4]. Therefore, a careful history should be taken for exclusion of rhabdomyolysis in the differential diagnosis.

Rhabdomyolysis in PBSC donors associated with G-CSF mobilization is very rare. Previously, only two cases have been documented during mobilization with lenograstim [5]. In this paper, we report a 6-year-old allogeneic PBSC donor who developed rhabdomyolysis following mobilization with filgrastim.

\section{Case Report}

A 14-year-old female was diagnosed with acute myeloid leukemia. After receiving standard remission induction chemotherapy, she achieved the first complete remission of her leukemia. Thereafter, she received a consolidation course of chemotherapy composed of high dose cytosine arabinoside. Finally, she was scheduled for allogeneic stem cell transplantation from her HLA-matched 6-year-old sister; informed consent was received from the parent.

Prior to recruitment, the donor underwent a detailed physical and laboratory examination. Her previous history was unremarkable. All pediatric vaccines had been administered. There was no history of disease or drug use. Her physical examination, chest X-ray, electrocardiogram, complete blood counts, blood chemistry profile, and parameters of hemostasis were normal. Viral serology regarding hepatitis A, B, and C, Epstein-Barr virus, herpes 1 and 2, cytomegalovirus, adenovirus, influenza virus, cocksackie, echo, varicella zoster, and human immunodefficiency virus were negative.

The donor received $10 \mu \mathrm{g} / \mathrm{kg}$ per dose of filgrastim (Neupogen ${ }^{\mathrm{TM}}$, Amgen-Roche, Thousand Oaks, CA, USA) subcutaneously once daily for 5 days. On the 3rd day of filgrastim, the donor complained of bone pain; paracetamol was given as a single dose $(250 \mathrm{mg})$. On the 4 th day of G-CSF administration, a central venous catheter was implanted in the subclavian region. The patient did not receive any additional drugs or anesthetics for catheter implantation. She complained of bone pain, myalgia, and vomiting 6-8 h after the catheter was placed, at which time she was reevaluated. Physical examination was unremarkable. Body temperature, respiration rate, and blood pressure were within normal ranges. Urine was tea-colored. Laboratory analysis was as follows: serum creatine phosphokinase (CK) was 1,095 U/1 (40-226 U/1), LDH 312 U/1 (100-190 $\mathrm{U} / \mathrm{l})$, AST $85 \mathrm{U} / \mathrm{l}(0-40 \mathrm{U} / \mathrm{l})$, uric acid $8.5 \mathrm{mg} / \mathrm{dl}(2.6-8 \mathrm{mg} / \mathrm{dl})$, and potassium $3.3 \mathrm{mmol} / \mathrm{l}(3.6-5.1 \mathrm{mmol} / \mathrm{l})$. The other serum biochemistry variables were within normal ranges. In complete blood count, hemoglobin was $12.5 \mathrm{~g} / \mathrm{dl}$, white blood cell count $39,800 / \mu \mathrm{l}$, and platelet count $350,000 / \mu \mathrm{l}$. A peripheral blood smear revealed leukocytosis with a left shift. Urine myoglobin level was $110 \mathrm{ng} / \mathrm{ml}$ (normal range $<5 \mathrm{ng} / \mathrm{ml}$ ).

Rhabdomyolysis was suspected on clinical and laboratory examination evaluation, and intravenously forced diuresis with potassium replacement was initiated. Central venous pressure was closely monitored. After $12 \mathrm{~h}$ clinical findings resolved and serum CK level started to decrease. Subsequently, the patient's muscular symptoms improved, with laboratory values returning to normal after 3 days. G-CSF administration was continued after diagnosis of rhabdomyolysis and initiation of diuretic treatment. Stem cells were appropriately harvested from peripheral blood on the 5th day of G-CSF therapy, and CK value did not increase after stem cell apheresis.

\section{Discussion}

Rhabdomyolysis is a syndrome that results from muscle injury, lysis, and degeneration leading to the release of intracellular contents into the blood and urine. Rhabdomyolysis may be associated with life-threatening complications, e.g. acute renal failure, cardiac arrhythmias, and disseminated intravascular coagulopathy. The mortality rate may still be as high as $8 \%$. Therefore, to prevent rhabdomyolysis-associated severe complications, early diagnosis and therapy are crucial. Additionally, overall prognosis of rhabdomyolysis is favorable with early diagnosis and treatment. The development of rhabdomyolysis is associated with a wide variety of diseases, injuries, medications, and toxins [6, 7]. Nearly $80 \%$ of cases of rhabdomyolysis are drug-related [7]. It can also be an unusual complication of high-dose chemotherapy and hematopoietic stem cell transplantation [8]. Several chemotherapy agents causing rhabdomyolysis have been previously reported [9-12]. However, the rhabdomyolysis in healthy allogeneic stem cell donors during PBSC mobilization is extremely rare [5]. The criteria of rhabdomyolysis, i.e. a more than 5-fold increase of CK, were met in these 2 cases. Additionally, there was no evidence of other diseases as a cause for rhabdomyolysis in these donors; in particular, viral causes such as adenovirus, cytomegalovirus, influenza virus, cocksackie, echo, herpes simplex, varicella zoster, or Epstein-Barr virus were not detected. Hence, there are two probable causes regarding rhabdomyolysis in our donor. One is that rhabdomyolysis is a direct adverse effect of filgrastim or paracetamol. The other is that rhabdomyolysis is secondary to the combined adverse effect of these two agents. On the other hand, we can not prove whether or not 
central venous catheterization may have caused rhabdomyolysis in our case. There are a few cases of myoglobinuria, especially following cardiac catheterization [13, 14]. However, we could not find any report regarding rhabdomyolysis associated with it.

Drug-induced rhabdomyolysis can occur by a primary direct toxic effect on the myocyte function or by an indirect secondary effect that predisposes the myocyte to develop injury [15]. However, the exact mechanism of rhabdomyolysis caused by these agents is not clearly known. To our knowledge, paracetamol alone, despite its widespread use, has caused myopathy in only 3 patients, one of whom suffered from hypersensitivity-associated rhabdomyolysis; the remaining 2 had toxic paracetamol-induced rhabdomyolysis [16-18]. This is the first documented case of rhabdomyolysis after administration of filgrastim.
The frequency and severity of rhabdomyolysis after G-CSF and/or paracetamol remain unclear. Some cases with mild or moderate rhabdomyolysis may be undiagnosed during G-CSF administration if $\mathrm{CK}$ monitoring is not performed. However, severe rhabdomyolysis can be associated with life-threatening complications. Therefore, allogeneic stem cell donors should be closely monitored with regard to rhabdomyolysis after/during G-CSF administration and following hemapheresis. If rising CK levels are observed during G-CSF mobilization associated with mild or moderate rhabdomyolysis, urgent treatment may be initiated without discontinuation of G-CSF.

\section{Disclosure}

The authors declared no conflict of interest.

\section{References}

1 Takeyama K, Ohto H: PBSC mobilization. Transfus Apher Sci 2004;31:233-243.

2 Tigue CC, McKoy JM, Evens AM, Trifilio SM, Tallman MS, Bennett CL: Granulocyte-colony stimulating factor administration to healthy individuals and persons with chronic neutropenia or cancer: an overview of safety considerations from the Research on Adverse Drug Events and Reports Project. Bone Marrow Transplant 2007;40:185-192.

$\checkmark 3$ Knochel JP: Rhabdomyolysis and myoglobinuria. Annu Rev Med 1982:33:435-443.

4 Mannix R, Tan ML, Wright R, Baskin M: Acute pediatric rhabdomyolysis: causes and rates of renal failure. Pediatrics 2006;118:2119-2125.

5 Schanz J, Wolf C, Koehler M, Maas JH, Meyer M, Neumeyer H, Legler TJ, Wulf G, Glass B, Truemper L, Riggert J: Rhabdomyolysis in allogeneic peripheral blood stem cell donors. Vox Sang 2004; 86:263-265.

6 Bagley WH, Yang H, Shah KH: Rhabdomyolysis. Intern Emerg Med 2007;2:210-218.

7 Prendergast BD, George CF: Drug-induced rhabdomyolysis: mechanisms and management. Postgrad Med J 1993;69:333-336.
Jackson SR, Barnett MJ, Keller O, Nantel SH, Phillips GL: Recovery from rhabdomyolysis after allogeneic BMT: report of a case with speculation on causation. Bone Marrow Transplant 1995;15:803804.

9 Koeffler HP, Haskell CM: Rhabdomyolysis as a complication of 5-azacytidine. Cancer Treat Rep 1978;62:573-574.

10 Pugliese P, Danova M, Brugnatelli S, Piccolo G, Riccardi A, Ascari E: Acute rhabdomyolysis after high dose chemotherapy and circulating progenitor cell autografting for breast cancer. Haematologica 2000;85:672.

11 Margolis D, Ross E, Miller KB: Rhabdomyolysis associated with high-dose cytarabine. Cancer Treat Rep 1987;71:1325-1326.

12 Tabata N, Tanaka R, Suga S, Mitani Y, Nakano T, Ido M, Azuma E, Ito M, Hamazaki M, Shiraishi T, Sakurai M: Rhabdomyolysis following administration of cyclophosphamide: a case report in a BMT recipient. Bone Marrow Transplant 1996;17:11671169.
3 Donald TG, Cloonan MJ, Wilcken DE: Excretion of myoglobin in urine after cardiac catheterisation. Br Heart J 1978;40:1237-1242.

14 McComb JM, McMaster EA: Serum myoglobin after cardiac catheterisation. Br Heart J 1982;47: 353-356.

15 Ellenhorn MJ: Ellenhorn's Medical Toxicology, Diagnosis and Treatment of Human Poisoning, ed 2. Baltimore, Williams and Wilkins, 1997.

16 Moneret-Vautrin DA, Guerin L, Kanny G, Flabbee J, Fremont S, Morriset M: Acetaminophen-induced rhabdomyolysis. Allergy 1990;54:1115-1116.

17 Waakel RA, Davies HT, Williams JD: Toxic myocarditis in paracetamol poisoning. Br Med J 1987;295:1097.

18 Yang CC, Deng JF, Lin TJ: Pancytopenia, hyperglycemia, shock, coma, rhabdomyolysis, and pancreatitis associated with acetaminophen poisoning. Vet Hum Toxicol 2001;4:344-348. 